\title{
Audit Opinion and Earnings Quality: Evidence from Korea
}

\author{
Seon-Ju Yoon \\ College of Business Administration, Inha University, 100 Inha-ro, Michuhol-gu, Incheon 22212, KOREA \\ Jaimin Goh \\ College of Business Administration, Inha University, 100 Inha-ro, Michuhol-gu, Incheon 22212, KOREA \\ Jin-Young Jung* \\ College of Business Administration, Inha University, 100 Inha-ro, Michuhol-gu, Incheon 22212, KOREA \\ E-mail: jyjung@inha.ac.kr
}

\begin{abstract}
This study examines whether the decrease in qualified opinions is due to improved accruals quality. The proportion of qualified opinions has been declining in Korea for about 10 years. However, it has not been reported that earnings quality has improved. We analyze this contradictory relationship using two models. We find that Korean firms' accruals quality has no association with unqualified opinions. This means that the increasing trend in unqualified opinions is occurring regardless of earnings quality, although audit opinion chiefly depends on it. Thus, our results suggest that more researches are required to determine why qualified opinions are declining.
\end{abstract}

Keywords: audit opinion; earnings quality; accruals

DOI: $10.7176 / \mathrm{EJBM} / 12-30-02$

Publication date:October $31^{\text {st }} 2020$

\section{Introduction}

Auditors generate audit opinions, which reduce the asymmetry between firms and investors [1-3]. The audit opinion is affected not only by firms' financial condition but also by the audit environment [4-6]. This means that auditors are affected by their independence in terms of information quality.

This study examines whether improvements in accruals quality increases the proportion of unqualified opinions. We are interested in this relationship because the proportion of unqualified opinions increased consistently around 2010 in the Korean capital market. We therefore investigate whether this increase came from good accruals quality given the research finding that auditors are prone to give a qualified opinion to bad accruals quality $[7,8]$.

We cannot find a significant relationship between firms' accruals quality and unqualified auditor opinion. Thus, auditors' audit opinion may not offer useful information to investors. Moreover, our finding implies that investors may be skeptical of auditors' independence from managers.

This study asks why the percentage of unqualified opinions is high regardless of accruals quality. However, it does not investigate detailed accounting titles regarding audit opinions. Such an analysis could help researchers reveal the hidden cause of the high proportion of unqualified opinions.

The rest of this paper is organized as follows. Section 2 reviews the literature and establishes the study's hypothesis. Section 3 explains the study's variables, samples, and empirical models. Section 4 presents the descriptive statistics and results of the study. Finally, Section 5 concludes the paper.

\section{Literature Review and Hypothesis}

The audit opinion explains whether investors should trust the firms' financial statements. A qualified opinion warns investors to be careful in considering the accounting numbers in the financial statement. Therefore, the audit opinion is important in that it can provide useful information to market participants.

Francis and Krishnan [7] analyze accounting conservatism among auditors using data on US firms. They suggest that the audit opinion provides information on the possibility of cash realization. Bartov et al. [8] report a significant relationship between discretionary accruals and qualified opinions using the Jones model [9] and a modified Jones model [10].

However, audit opinions can be affected by the independence of the auditors. Chow and Rice 4] show that auditors tend to be replaced after giving qualified opinions, and Lennox [5] finds that managers are more likely to hire a new auditor when auditors give unfavorable audit opinions on the firm.

These results suggest that managers often engage in "audit opinion shopping" by hiring a new auditor. This also applies to Korean firms. Using the findings of Lennox [5], Choi and Jung [6] examine if audit opinion shopping is common in the Korean market. They show that an increased possibility of a qualified opinion increases managers' tendency to replace their auditors; it is also unlikely that current auditors will be hired again if there is little chance of an unqualified opinion for the next year. Moreover, auditor change via audit opinion shopping is 
associated with greater discretionary accruals in earnings management. Thus, audit opinions are affected by pressure regarding rehiring, which can impair auditor independence.

Bradshaw et al. [11] investigate whether auditors and financial analysts warn investors about the financial consequences of high accounting accrual levels. They find no evidence that financial analysts and auditors act as information intermediaries when accounting accruals are at high levels. Using US data from 1994 to 1999, Butler et al. [12] show that there is no relationship between discretionary accruals and audit opinion. Contrariwise, Herbohn and Ragunathan [13] argue that there is a negative relation between discretionary accruals and qualified opinion.

Table 1 presents each year's accruals quality based on qualified and unqualified opinions using the Jones [9] and modified Jones models [10]. As shown in panels A and B, the figures for accruals quality are similar in the two audit opinion groups.

Figure 1 shows the proportion of qualified opinion for each year. Each year's figure is calculated as the number of qualified opinions divided by that of all audit opinions. 33The proportion of qualified opinions decreases overall. Table 1 and Figure 1 indicate that auditors give unqualified opinions regardless of the firm's accrual quality. Based on the literature and our two preliminary analyses, we propose the following null hypothesis:

Hypothesis: Audit opinion is not related to the quality of accounting accruals.

Table 1. Comparison of accruals quality between unqualified and qualified opinion

\begin{tabular}{|c|c|c|c|c|}
\hline \multirow[b]{2}{*}{ Year } & \multicolumn{2}{|c|}{$A Q 1$} & \multicolumn{2}{|c|}{$A Q 2$} \\
\hline & $\begin{array}{l}\text { Unqualified } \\
\text { opinion }\end{array}$ & $\begin{array}{l}\text { Qualified } \\
\text { opinion }\end{array}$ & $\begin{array}{c}\text { Unqualified } \\
\text { opinion }\end{array}$ & $\begin{array}{c}\text { Qualified } \\
\text { opinion }\end{array}$ \\
\hline 2003 & -0.07 & -0.06 & -0.07 & -0.07 \\
\hline 2004 & -0.06 & -0.06 & -0.06 & -0.06 \\
\hline 2005 & -0.06 & -0.1 & -0.06 & -0.1 \\
\hline 2006 & -0.06 & -0.06 & -0.06 & -0.08 \\
\hline 2007 & -0.06 & -0.07 & -0.06 & -0.06 \\
\hline 2008 & -0.08 & -0.11 & -0.08 & -0.11 \\
\hline 2009 & -0.06 & -0.06 & -0.06 & -0.06 \\
\hline 2010 & -0.06 & -0.06 & -0.06 & -0.05 \\
\hline 2011 & -0.07 & -0.02 & -0.07 & -0.02 \\
\hline 2012 & -0.05 & -0.19 & -0.05 & -0.21 \\
\hline 2013 & -0.04 & -0.17 & -0.04 & -0.18 \\
\hline 2014 & -0.05 & -0.05 & -0.05 & -0.05 \\
\hline Pooled & -0.06 & -0.09 & -0.06 & -0.09 \\
\hline
\end{tabular}

AQ1 = accruals quality via Jones model [9]; AQ2 = accruals quality via modified Jones model [10]

Figure 1. Trend in proportion of qualified opinions

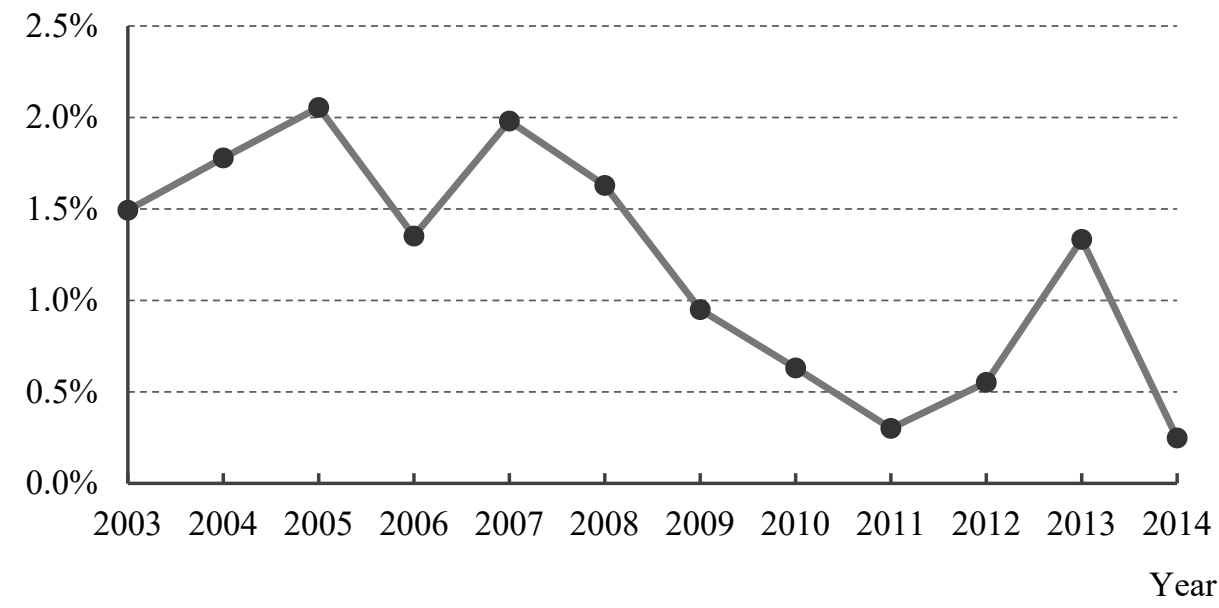

\section{Methodology}

\subsection{Estimation of Accruals Quality}

This study uses the Jones [9] and modified Jones [10] models to proxy for earnings quality. These two models are widely used to calculate discretionary accruals; earnings quality is dependent on accounting accruals.

First, we estimate accruals quality by determining the discretionary accruals using equations (1) and (2), which 
are based on Jones [9] and Dechow et al. [10]. We then multiply the measures by (-1) because accruals quality decreases as the absolute value of discretionary accruals increases.

$$
\begin{aligned}
& \frac{T A C_{t}}{A_{t-1}}=\alpha_{0} \frac{1}{A_{t-1}}+\alpha_{1} \frac{\Delta S A L E S_{t}}{A_{t-1}}+\alpha_{2} \frac{P P E_{t}}{A_{t-1}}+\epsilon \\
& \frac{T A C_{t}}{A_{t-1}}=\alpha_{0} \frac{1}{A_{t-1}}+\alpha_{1} \frac{\Delta S A L E S_{t}-\Delta R E V_{t}}{A_{t-1}}+\alpha_{2} \frac{P P E_{t}}{A_{t-1}}+\epsilon \\
& A Q_{t}=|\varepsilon| \times(-1) \\
& \text { where } \\
& T A C=\text { total accruals (net income - cash flow from operation); } \\
& A=\text { total assets; } \\
& S A L E S=\text { total revenue; } \\
& R E V=\text { accounting receivables; } \\
& P P E=\text { property, plant, and equipment. }
\end{aligned}
$$

\subsection{Empirical Model}

This study examines the effect of accruals quality on auditors' audit opinions. We employ logistic linear regression using the dependent variable OPN, set to 1 if the audit opinion is unqualified opinion and 0 otherwise. The main explanatory variable is accruals quality, AQ, which is defined as AQ1 (Jones model) and AQ2 (modified Jones model). If auditors are more likely to give an unqualified opinion for high-quality earnings, the regression coefficient of AQ should be positive. However, if earnings quality does not affect the audit opinion, the coefficient should not be significant. Thus,

$$
\begin{aligned}
& O P N_{t}=\alpha_{0}+\alpha_{1} A Q_{t}+\alpha_{2} B I G 4_{t}+\alpha_{3} I F R S_{t}+\alpha_{4} S I Z E_{t}+\alpha_{5} L E V_{t}+\alpha_{6} B T M_{t}+\quad \alpha_{7} R O A_{t}+\alpha_{8} F O R_{t}+ \\
& \sum Y R+\sum I N D+\varepsilon
\end{aligned}
$$

where

$O P N=1$ if audit opinion is unqualified and 0 otherwise;

$A Q=$ accruals quality;

$A Q 1=$ accruals quality estimated by Jones model [9];

$A Q 2$ = accruals quality estimated by modified Jones model [10];

Big4 $=1$ if auditor is a Big 4 and 0 otherwise;

$I F R S=1$ if year is after IFRS adoption (2011-2014) and 0 otherwise;

$S I Z E=\ln ($ total assets);

$L E V=$ total liability/total assets;

$B T M=$ book value of equity/market value of equity;

$R O A=$ net income/total assets;

$F O R=$ foreign investor ownership.

The study's control variables are as follows. BIG4 is a dummy variable set to 1 if the auditor is a Big Four accounting firm. Generally, these firms are known to provide a high quality of audit service and to run a more strict review. However, they may compromise audit opinion because Big Four accounting firms cost more when they lose the auditee firm. IFRS is used to control for the 2011 change in accounting standards from the Generally Accepted Accounting Principle (K-GAAP) to the International Financial Reporting Standards (K-IFRS). K-IFRS enables managers to have more accounting discretion, and it has made the auditors' role more important. The variable is set to 1 for years since 2011, when K-IFRS became mandatory.

Firm size can affect the independence of an auditor [14]. SIZE is the logarithm of total assets. LEV is the value of total liabilities divided by total assets. Highly levered firms are prone to receiving unfavorable audit opinions because a higher debt ratio implies lower financial soundness. BTM is the book value to the market price of stocks. Generally, firm assets are undervalued when BTM is low, which leads to a high probability of mergers and acquisitions and lawsuits [15]. When the potential for lawsuits is high, auditors are prone to give unfavorable opinions. ROA is return on assets, reflecting firms' profitability. High firm performance is a positive signal for audit opinions. FOR is the percentage of foreign investor ownership. Foreign investors demand quality not only in earnings but also in audits; thus, they tend to make audit opinions more conservative [16].

\subsection{Sample Selection}

For the empirical analysis, we collect data on firms listed in the Korean stock market from 2003 to 2014 . We download financial and audit opinion data from the FnGuide database, excluding observations with insufficient information. To ensure homogeneity among the observations, we exclude observations in which the fiscal yearend is not December, observations for financial institutions, and observations with impaired capital. To ensure reliability in the estimation of discretionary accruals, observations with fewer than 20 industry-years are filtered 
out. Finally, we winsorize the observations at the top and bottom $1 \%$ to control for the effect of outliers. The final sample used in the analysis consists of 3,854 firm-year observations.

\section{Empirical Analysis}

4.1 Univariate Analyses

Table 2 presents the descriptive statistics of the variables. The mean value of OPN, reflecting unqualified opinion, is 0.989 . This indicates that about $99 \%$ of the observations receive an unqualified opinion, consistent with the data in Figure 1. The means of explanatory variables AQ1 and AQ2, reflecting accruals quality as calculated by the Jones and modified Jones models, are -0.060 and -0.060 , respectively.

Table 3 presents the correlation of each variable. The variables for quality of earnings (AQ1 and AQ2) are significantly correlated with the variable for audit opinion (OPN), at 0.049 and 0.057 , respectively. These correlation coefficients indicate that higher accruals quality increases the chance of an unqualified opinion. An unqualified audit opinion is positively correlated with all the control variables except for LEV and BTM. We find that auditors are more likely to give unqualified opinions when the auditor is a Big Four accounting firm and after K-IFRS is adopted. Moreover, firms with more foreign investor ownership tend to receive an unqualified opinion. Table 2. Descriptive statistics.

\begin{tabular}{c|cccccc}
\hline Variables & Obs. & Mean & STD & Minimum & Median & Maximum \\
\hline OPN & 3,854 & 0.989 & 0.106 & 0.000 & 1.000 & 1.000 \\
$A Q 1$ & 3,854 & -0.060 & 0.064 & -0.355 & -0.042 & -0.001 \\
$A Q 2$ & 3,854 & -0.060 & 0.061 & -0.337 & -0.042 & -0.001 \\
$B I G 4$ & 3,854 & 0.673 & 0.469 & 0.000 & 1.000 & 1.000 \\
$I F R S$ & 3,854 & 0.388 & 0.487 & 0.000 & 0.000 & 1.000 \\
SIZE & 3,854 & 19.776 & 1.560 & 16.908 & 19.536 & 24.245 \\
$L E V$ & 3,854 & 0.469 & 0.196 & 0.083 & 0.472 & 0.932 \\
BTM & 3,854 & 1.606 & 1.183 & 0.148 & 1.299 & 6.607 \\
ROA & 3,854 & 0.020 & 0.089 & -0.450 & 0.031 & 0.190 \\
FOR & 3,854 & 10.425 & 14.272 & 0.000 & 3.959 & 66.522 \\
\hline
\end{tabular}

Variable definitions:

$O P N=1$ if audit opinion is unqualified and 0 otherwise;

$A Q=$ accruals quality;

$A Q 1=$ accruals quality estimated by Jones [9] model;

$A Q 2$ = accruals quality estimated by modified Jones model [10];

Big4 $=1$ if auditor is Big 4 and 0 otherwise;

$I F R S=1$ if year is after IFRS adoption (2011-2014) and 0 otherwise;

$S I Z E=\ln ($ total assets);

$L E V=$ total liabilities/total assets;

$B T M=$ book value of equity/market value of equity;

$R O A=$ net income/total assets;

$F O R=$ foreign investor ownership. 
Table 3. Correlation matrix.

\begin{tabular}{c|ccccccccc}
\hline & $A Q 1$ & $A Q 2$ & $B I G 4$ & $I F R S$ & $S I Z E$ & $L E V$ & $B T M$ & $R O A$ & $F O R$ \\
\hline \multirow{2}{*}{$O P N$} & 0.049 & 0.057 & 0.128 & 0.040 & 0.052 & -0.017 & 0.018 & 0.031 & 0.044 \\
& $(0.002)$ & $(0.000)$ & $(<.0001)$ & $(0.012)$ & $(0.001)$ & $(0.297)$ & $(0.276)$ & $(0.053)$ & $(0.006)$ \\
$A Q 1$ & & 0.933 & 0.091 & 0.095 & 0.181 & -0.154 & 0.049 & 0.272 & 0.110 \\
& & $(<.0001)$ & $(<.0001)$ & $(<.0001)$ & $(<.0001)$ & $(<.0001)$ & $(0.002)$ & $(<.0001)$ & $(<.0001)$ \\
$A Q 2$ & & & 0.075 & 0.086 & 0.141 & -0.163 & 0.055 & 0.264 & 0.091 \\
& & & $(<.0001)$ & $(<.0001)$ & $(<.0001)$ & $(<.0001)$ & $(0.001)$ & $(<.0001)$ & $(<.0001)$ \\
BIG4 & & & & 0.057 & 0.387 & 0.033 & 0.117 & 0.128 & 0.261 \\
& & & & $(0.000)$ & $(<.0001)$ & $(0.039)$ & $(<.0001)$ & $(<.0001)$ & $(<.0001)$ \\
IFRS & & & & & 0.188 & 0.108 & -0.018 & -0.120 & -0.046 \\
& & & & & $(<.0001)$ & $(<.0001)$ & $(0.265)$ & $(<.0001)$ & $(0.004)$ \\
SIZE & & & & & & 0.193 & -0.042 & 0.195 & 0.442 \\
& & & & & & $(<.0001)$ & $(0.010)$ & $(<.0001)$ & $(<.0001)$ \\
$3 L E V$ & & & & & & & -0.052 & -0.327 & -0.154 \\
& & & & & & & $(0.001)$ & $(<.0001)$ & $(<.0001)$ \\
BTM & & & & & & & -0.056 & -0.195 \\
& & & & & & & & $(0.001)$ & $(<.0001)$ \\
ROA & & & & & & & & & $(<.0001)$ \\
\hline
\end{tabular}

Refer to Table 1 for variable definitions; values in parentheses are p-values.

\subsection{Regression Results}

Table 4 shows the results of the regression analysis. As this study examines whether the decrease in qualified audit opinions is due to improved earnings quality, we investigate whether accruals quality affects the audit opinion. The result of the logistic linear regression shows that audit opinion is not significantly related to accruals quality as derived by the Jones (AQ1) and modified Jones models (AQ2). We therefore cannot reject the null hypothesis and conclude that the proportion of qualified audit opinions is declining regardless of accruals quality.

Among the control variables, the dependent variable is positively associated with BIG4, IFRS, and BTM. Therefore, firms are prone to receiving unqualified opinions when the auditor works for a Big Four accounting firm, when the firm's assets are undervalued, and after Korean firms adopted K-IFRS.

Table 4. Effect of accruals quality on audit opinion.

\begin{tabular}{|c|c|c|c|c|}
\hline \multirow{2}{*}{ Variables } & \multicolumn{2}{|c|}{$A Q 1$} & \multicolumn{2}{|c|}{$A Q 2$} \\
\hline & Estimate & Wald value & Estimate & Wald value \\
\hline Intercept & 7.89 & $6.15 * *$ & 8.32 & $6.82 * * *$ \\
\hline$A Q$ & 1.28 & 0.41 & 2.80 & 1.86 \\
\hline$B I G 4$ & 2.84 & $27.69 * * *$ & 2.85 & $27.57 * * *$ \\
\hline IFRS & 2.24 & $4.29 * *$ & 2.22 & $4.20 * *$ \\
\hline SIZE & -0.17 & 1.10 & -0.19 & 1.32 \\
\hline$L E V$ & -0.78 & 0.71 & -0.74 & 0.64 \\
\hline$B T M$ & 0.47 & $5.76^{* *}$ & 0.45 & $5.26 * *$ \\
\hline$R O A$ & 0.14 & 0.01 & -0.10 & 0.00 \\
\hline FOR & 0.02 & 0.50 & 0.02 & 0.53 \\
\hline Year Dummies & \multicolumn{2}{|c|}{ Included } & \multicolumn{2}{|c|}{ Included } \\
\hline Industry Dummies & \multicolumn{2}{|c|}{ Included } & \multicolumn{2}{|c|}{ Included } \\
\hline \# of Obs. & \multirow{2}{*}{\multicolumn{2}{|c|}{$\begin{array}{c}3,854 \\
125.16^{* * *}\end{array}$}} & \multirow{2}{*}{\multicolumn{2}{|c|}{$\begin{array}{c}3,854 \\
126.53^{* * *}\end{array}$}} \\
\hline Likelihood ratio & & & & \\
\hline
\end{tabular}

$*, * *$, and $* * *$ represent significance at the $10 \%, 5 \%$, and $1 \%$ levels, respectively.

\section{Conclusion}

This study is motivated by the fact that most Korean listed firms receive unqualified audit opinions and that this tendency is increasing. The study seeks to determine whether these unqualified opinions are due to accruals quality. 
The literature argues that audit opinions provide reliable information as long as auditors tend to give unfavorable opinions on low-quality earnings [7,8]. However, recent studies show that managers tend to opinion-shop, which can damage auditors' independence and lower the reliability of their information and its usefulness to investors [5,11-13]. The high proportion of unqualified audit opinions should ideally be related to the quality of earnings; the lack of such a relationship would compromise the value of information related to audit opinion.

We use data on KOSPI listed firms covering 2003 to 2014 to analyze the relationship between audit opinion and accruals quality. The empirical result shows that the high proportion of unqualified opinions is not related to the quality of accruals, implying that auditors' opinions have doubtful informational value.

This study has several limitations. It measures the quality of earnings only using the estimation model. Future research should extend our study by analyzing specific accounting titles. Moreover, future studies should determine if the empirical results vary according to the type of auditors considered. Also, future studies need to discover the hidden driver of the increasing proportion of unqualified audit opinions.

Author Contributions: Conceptualization, J.G. and S.Y.; methodology, J.G. and S.Y.; software, J.G. and S.Y.; validation, J.G. and J.J.; formal analysis, J.J.; investigation, J.J.; writing - original draft preparation, S.Y.; writing-review and editing, J.G.; supervision, J.J.

Funding: This research received no external funding.

Acknowledgments:

Conflicts of Interest: The authors declare no conflict of interest.

\section{References}

1. Mutchler, J. F.; Hopwood, W.; McKeown, J. M. The influence of contrary information and mitigating factors on audit opinion decisions on bankrupt companies. J. Account. Res. 1997, 35, 295-310.

2. Chen, P. F.; He, S.; Ma, Z.; Stice, D. The information role of audit opinions in debt contracting. J. Account. Econ. 2016, 61, 121-144.

3. Abda, D.; Sanchez-Ballesta, J. P.; Yague, J. Audit opinions and information asymmetry in the stock market. Account. Financ. 2017, 57,565-595.

4. Chow, C.W.; Rice, S.J. Qualified audit opinions and auditor switching. Account. Rev. 1982, 57, 326-335.

5. Lennox, C.S. Do companies successfully engage in opinion-shopping? Evidence from the UK. J. Account. Econ. 2000, 29, 321-337.

6. Choi, J.H.; Jung, H.S. Auditor change for audit opinion shopping and impairment of audit quality. Korean Bus. Rev. 2015, 44, 1575-1607.

7. Francis, J.R.; Krishnan, J. Accounting accruals and auditor reporting conservatism. Contemp. Account. Res. $1999,16,135-165$.

8. Bartov, E.; Gul, F.A.; Tsui, J.S.L. Discretionary-accruals models and audit qualifications. J. Account. Econ. 2001, 30, 421-452.

9. Jones, J.J. Earnings management during import relief investigations. J. Account. Res. 1991, 29, $193-228$.

10. Dechow, P.M.; Sloan, R.G.; Sweeney, A.P. Detecting earnings management. Account. Rev. 1995, 70, 193225.

11. Bradshaw, M.T.; Richardson, S.A.; Sloan, R.G. Do analysts and auditors use information in accruals? J. Account. Res. 2001, 39, 45-74.

12. Butler, M.; Leone, A.J.; Willenborg, M. An empirical analysis of auditor reporting and its association with abnormal accruals. J. Account. Econ. 2004, 37, 139-165.

13. Herbohn, K.; Ragunathan, V. Auditor reporting and earnings management: Some additional evidence. Account. Financ. 2008 48(4), 575-601.

14. DeFond, M.L.; Raghunandan, K.; Subramanyam, K.R. Do non-audit service fees impair auditor independence? Evidence from going concern audit opinions. J. Account. Res. 2002, 40, 1247-1274.

15. Palepu, K.G. Predicting takeover targets a methodological and empirical analysis. J. Account. Econ. 1986, 8, 3-35.

16. Rho, J.H.; Bae, G.S.; Cheon, Y.S. Do firms with large agency costs choose high quality audits? A comparison of the audit quality between foreign-direct-investment-firms and local firms. Korean Account. Rev. 2003, 28, $203-230$. 